\title{
ALIENATION AND ANXIETY IN TOURISM MOTIVATION
}

\begin{abstract}
Although underexplored in tourism studies, recent work suggests theories of alienation, as the dialectic of authenticity, have much to contribute to our understanding of tourism motivation. This paper uses three major theoretical tropes (Marxism, existentialism, and Lacanian psychoanalysis) to examine the role of alienation in the motivations of hiking and rock climbing tourists. In particular, these tourists describe only temporary and retrospective relief from anxiety, articulating authenticity as an elusive experience that lies at the horizon, in the next adventure, or in the past as a memory. Alienation is an ever-present component of the human condition, and as such, anxiety is omnipresent in our lives, contributing significantly to touristic desires for escape, rejuvenation, and existential experiences.
\end{abstract}

Keywords: alienation, anxiety, authenticity, hiking, motivation, rock climbing, nature

\section{INTRODUCTION}

\begin{abstract}
"[A]uthenticity is only possible once the taken-for-granted world and the security it offers are called into question. This is dependent on a specific mood - anxiety - which, in subjecting everydayness to questioning, reveals the groundlessness of human existence" (Turner \& Manning, 1988, p.137)
\end{abstract}

Tourism literature increasingly attends to notions of alienation, adding to already rich discussions of authenticity; yet, there has been little investigation of anxiety and its role as embodied alienation in motivating the search for authenticity (with exception of Kirillova, et al. 2017). While MacCannell $(1976,1999)$ took note of the role of alienation in modern society and its relationship to the ritual aspects of tourism and Cohen (1979) posited that alienation plays a role in the need for escape and recreation, the relations among anxiety, alienation, and authenticity have yet to be effectively articulated, particularly in relation to tourist motivation. Based on data collected from hiking and rock climbing tourists in the Adirondack Park, New York, USA, and Red River Gorge, Kentucky, USA, respectively, this paper explores several notions of alienation to address anxiety as embodied alienation in relation to touristic motivation, and to further elaborate on the elusiveness of authenticity. Seeman (1959) identified five manifestations of alienation: powerlessness, meaninglessness, normlessness, isolation, and selfestrangement. We focus on the feeling of anxiety that accompanies these and its power as an acute motivator or push factor (Maoz, 2006) in tourists' quests for authenticity. While existentialist approaches (see Wang 1999; Steiner \& Reisinger 2006) attempt to identify ways of resolving alienation through existential authenticity, this paper argues that alienation and its embodiment as anxiety maintain a dialectical relationship with authenticity and as a result can never be fully satisfied. Nevertheless, while never resolved, we argue that alienation and anxiety act as important drivers in tourist motivation, spurring tourists on in their search for authentic experiences they believe may 
alleviate these unpleasant feelings. To illustrate this, we approach alienation through three major theoretical tropes: Marxism, existentialism, and Lacanian psychoanalysis.

Anxiety, that unfocused feeling of disquiet, dread, or concern, is an ever-present component of the human condition, and while it may be suppressed, it is always just under the surface, bubbling up at particular moments. Kingsbury et al. (2012, p. 369) define the term generally, stating " $[\mathrm{u}]$ nlike fear, anxiety does not usually have a specific perceivable focus, stimuli, event, or object". According to Kierkegaard (1844/1980), anxiety is related to fear and freedom of existential choice. It is what Heidegger (1927/1962) referred to as a mood that accompanies the desire for an authentic self, and which Sartre (1939/2002) further elaborated on as a feeling that is indicative of consciousness and Being-in-the-world. More generally, anxiety "manifests itself as a highly unsettling feeling of uneasiness that accompanies an individual throughout his or her life" (Kirillova et al., 2015, p.9; see also Kirillova, et al. 2017). Its omnipresence in our lives is due to the fact that it is the embodiment of alienation. Lacan (1949/2006) argued alienation is a constitutive condition of all social subjects, and as a result a social subject can never be rid of her/his alienated condition, can never attain the authentic, and thus may never escape anxiety. This, however, does not prevent the subject from embarking on quests to assuage feelings of anxiety by seeking the fantasy of authenticity (see Oakes, 2006; Knudsen, et al. 2016). In fact, this is arguably the most human of endeavors, as we each seek to alleviate our alienation through various means - travel, shopping, leisure, and so on. We argue that it is not just authenticity that drives our travel behavior but acute feelings of anxiety as embodied alienation that drive us to seek out the fantasy of authenticity in particular destinations.

\section{ALIENATION AND AUTHENTICITY IN TOURISM STUDIES}

Theories of alienation and authenticity are eclectic in nature, yet they nevertheless figure prominently in tourism literature. While authenticity has historically received more attention in the field, alienation, as "authenticity's forgotten cousin" has enjoyed increasing consideration since Rickly-Boyd's (2013) appeal for its greater inclusion in tourism scholarship and Xue, et al. (2014) elaborated on different perspectives of alienation at work in tourism (production, consumption, existential) (see also Knudsen et al., 2016). While MacCannell $(1976,1999)$ took note of the role of alienation in modern society and its relationship to the ritual aspects of tourism, Dann (1977) examined the experience of anomie as a push factor towards travel, and Cohen (1979) posited that alienation plays a role in the need for escape and recreation, the relations among anxiety, alienation, and authenticity have yet to be effectively articulated in this context. Indeed, Xue, et al. (2014, p.187) note that "the concepts of alienation and authenticity are complementary however they are neither equivalent nor interchangeable $[\ldots]$ alienation embodies a self-emancipatory vantage point and an intellectual pedigree that authenticity lacks." We suggest that this explanation of alienation and authenticity de-emphasizes the crucial relationship of these concepts, as dialectical, in which one does not exist without the other as they relationally define one another. 


\begin{abstract}
Marxism
Marx's notions of alienation have served as a foundation for early scholars pursuing theories of tourism involving alienation and authenticity (see author, 2013). Indeed, MacCannell (1976; 1999) contends that as individuals living in modern capitalist society, tourists are alienated and therefore seek the authentic in tourism sites and experiences. Entrenched in their everyday lives, they become more alienated from both self and society and thus more acutely aware of their own alienation, which prompts them to seek out the authentic outside of their daily lives in modernity. Invariably finding "staged authenticity", MacCannell contends that tourists nevertheless seek the authentic as a means to overcome their own alienation. What's more, "alienation seems to follow the travelers into their touristic adventures. The alienation takes the form of restricted choices framed by a 'staged' consumption pattern--a fetishism if you will--in which the singular theme of possession and display takes priority over all other social behavior" (Watson \& Kopachevsky, 1994, p.649).
\end{abstract}

In their recent categorization of alienation, Xue et al. (2014) include Marxist alienation within a broader understanding of "production" relations. In doing so, they shed light on the alienating working conditions of tourism and, importantly, extend the analysis of alienation beyond simply the tourists to those who work to make our holidays leisurely, carefree, rejuvenating, and recreational. Indeed, as Watson and Kopachevsky (1994, p.653) posit, by interpreting tourism as a commodity, we can reveal a particularly alienating structure of social relations: "those who demand, and those who supply--those who serve, and those who are served".

\title{
Existentialism
}

While MacCannell's use of alienation assumes a Marxist formulation, there has recently been a resurgence of scholars connecting alienation and authenticity vis-à-vis existentialism (see Wang, 1999; Maoz, 2006; Steiner \& Reisinger, 2006; Kirillova, et al., 2017). Existential authenticity is increasingly trumpeted as the antidote for the modern subject's alienated condition, itself a precondition for existential anxiety. This is a profoundly Western conceptualization of both concepts and one that harks back to Cohen's (1979) typology of authenticity and degrees of alienation and to Dann's (1977) work placing alienation squarely in the modern or postmodern condition. Wang (1999) further develops notions of alienation and authenticity to include bodily feelings, communitas, and self-making, while also maintaining that alienation in modernity drives individuals to seek out their authentic selves in the spaces apart from their everyday existence. He asserts, "work and everyday roles impose constraining and monotonous routine in which individuals find it difficult to pursue their self-realization [...] such routinization and over-predictability gives rise to the "feeling of loss"' (Giddens 1990, p.98 cited in Wang, 1999, p.363). It is this feeling of loss, this existential inauthenticity or alienation, then, that motivates individuals to engage in touristic activities. Xue et al. (2014, p.190) summarize this relationship thusly: "existential authenticity is attained when a person is cognizant of the mindless conformity that characterizes society and transcends this condition by choosing (in the Sartrean sense) to pursue projects that grant him/her meaning in life (be they leisure or work related)." This is, arguably, an optimistic 
interpretation as it suggests that existential authenticity is an attainable end goal, rather than episodic and requiring continual pursuit (see Steiner \& Reisinger, 2006).

More recently, Kirillova, et al. (2016, p.9) introduced the feeling of anxiety and the existential predicament into their research on tourist motivation and experience, asserting that by "making life fundamentally unsettled, [anxiety] functions as a springboard for existential authenticity when one seeks to reconcile the existential givens (meaninglessness of life, unconditional freedom, inevitable death, and universal alienation) with one's life pursuits". Moreover, Kirillova, et al. (2017) assert that transformative tourism experiences expose tourists of heightened sensitivity to existential anxiety. Rather than a pessimistic interpretation, we posit that Kirillova, et al.'s (2016; 2017) contention makes room for authenticity's dialectic, alienation, in touristic motivation. Further, they suggest that engagement with existential anxiety can have serious implications for lifestyle choices upon return from travel (see also Maoz, 2006; Brown, 2013; Kirillova \& Lehto, 2015). For example, Maoz's (2006, p.58) work with Israeli backpackers highlights the connections between alienation, crisis, and mode of touristic experience, as it draws attention not only to alienation and motivation, but adds to Cohen's (1979) typology by attending to crises associated with what she terms the "sociological clock". In summation, these existentialist approaches suggest authenticity and alienation operate dialectically in tourism motivation.

\section{Lacanian psychoanalysis}

Psychoanalytic perspectives are relatively new on the scene of the authenticity debate in tourism studies. Xue et al.'s (2014) identification of consumption alienation most closely relates to psychoanalytic understandings of alienation, as the authors touch on the role of desire and fantasy in consumer practices as a means to overcome alienation. Yet, this explanation only hints at the depths of psychological alienation and the power it has in regards to touristic motivations. Lacan's writings are increasingly applied to tourism studies, particularly the concepts of the ego (MacCannell, 2002), jouissance and sublimation (Kingsbury, 2011), as well as his development of concepts related to alienation, namely fantasy and objet petit a (Knudsen et al., 2016; Author, 2017). We focus principally on Lacanian psychoanalysis, however, because of the important ways his concepts such as jouissance, sublimation (Kingsbury, 2011, 2015) and the objet petit $a$ (Zizek, 2006; Kingsbury, 2010; Knudsen, et al., 2016; Author, 2017) have grown out of and remain central to alienation (see Knudsen, et al., 2016; Author, 2017). The objet petit $a$, for example, is related to the way alienation works as a mechanism in desire, and the ways wilderness, for instance, has become an objet petit $a$, a "socially sanctioned object of desire" (Author, 2017: 15) for many Americans. Thus, Lacanian psychoanalysis proves particularly appropriate in this particular study, as many of Lacan's concepts are tied directly to notions of alienation and are thus central to our efforts here. Through the Lacanian lens, we may better articulate the way relationships between alienation, authenticity, desire, fantasy, motivation, anxiety, and place are articulated in the tourism context. There are, of course, many other psychoanalytic thinkers that could be applied to tourism motivation as well. However, in this paper we aim to compare three theoretical perspectives on alienation more broadly, rather than assess the differences within each tradition. 
While not directly engaging with Lacanian psychoanalysis, Oakes (2006) paves the way for its use in his approach to authenticity as a paradox. He contends, authenticity "vaporizes only when you look for it" (p.250), a position well aligned with psychoanalytic perspectives on the ubiquity of alienation and the impossibility of attaining the authentic. Noting the utility of the concept in tourism, however, Oakes (2006, p.233) advances, "the search for authenticity is perhaps best thought of as a convenient code for something that in fact evaporates under scrutiny and yet remains nevertheless necessary as a framework for understanding the tourist experience". Working from Oakes' suggestions, Knudsen, et al. (2016) called authenticity a "fantasy", using Lacanian psychoanalytic theory, which posits that alienation, as constitutive of the social subject, forecloses the possibility of truly attaining the authentic, either in self or in experience. While Dann (1977, p.188) maintained that "the fantasy world of travel seeks to overcome the humdrum, the normlessness and meaninglessness of life, with more satisfying experiences", Knudsen, et al. assert that it is authenticity that is the fantasy. Further, it is a fantasy born of alienation, and thus constitutes a dialectical relationship between the two. Even if the authentic may never be realized, it provides a necessary fantasy that drives tourists' behaviors (see Knudsen, et al., 2016; Oakes, 2006).

In Kingsbury's (2011) ethnography of workers at Sandals Resorts Jamaica, alienation is demonstrated with the use of Lacan's concept of sublimation, which mobilizes the concept of enjoyment (Lacan's jouissance) to understand the ways enjoyment informs and is intertwined with commodification and management of workers towards tourism staging. Further, Kingsbury's work makes use of psychoanalytic theory to transcend the binary present in much of tourism literature, which pits the injustices of the workers against the happiness and enjoyment of the tourists. Through Lacan's concept of sublimation, Kingsbury contends that we may better articulate the nuances and entanglements between spaces of work and play and the people who create those spaces. Attention to the presence of the Real and to the role of fantasy opens the door to richer applications of psychoanalysis in tourism. As Kingsbury (2011, p.657) summarizes, sublimation is crucial to the reproduction of workers' exploitation and alienation, as well as guests' perceptions of authentic hospitality.

While these formulations increasingly attend to the dialectical relationship between alienation and authenticity, they nevertheless fall short in recognizing and elucidating the crucial role of anxiety as the embodiment of alienation. It is useful to consider the ways that a subject may feel alienated from herself, from society, or from nature, and the sources of that alienation as well as how it is embodied. While for Marx alienation finds its roots in capitalism, and existentialists claim that alienation's genesis lies in modernity, Lacan maintains that all social subjects are alienated and that alienation is inescapable. And while anxiety, as alienation embodied, motivates tourists to seek out the authentic in place, experience, community, and self, it may be alleviated no more than the alienated condition may be resolved through an engagement with the ephemeral authenticity. This should not be read as pessimistic, but rather as indicative of the power of alienation to motivate our travels (see for example, MacCannell, 1999). As the following analysis demonstrates, authenticity remains elusive; it lies at the horizon, in the next adventure, or 
in the past as a memory. Nevertheless, it remains a powerful desire in tourism motivation, as we seek to distance ourselves emotionally and spatially from the alienation of everyday life.

\section{RESEARCH DESIGN}

This paper examines the findings of two distinct studies that were both interested in tourists' motivations and experiences in relation to perceptions of authenticity and the natural environment. In what follows, brief descriptions of each site and the respective methods provide context. Combining the data collected at each of these sites allows for a more generalizable understanding of the ways anxiety and authenticity act as motivators in tourism, particularly nature-based and/or adventure tourism.

\section{Hikers in the Adirondack Park, New York, USA}

The Adirondack Park is a nearly six million acre area in Upstate New York known for its vast wilderness landscapes and recreational opportunities. Created in 1892 amid concerns for the area's timber and water resources, the Park has been increasingly popular among tourists. It is comprised of both public (State) and private land, including areas of designated wilderness as well as small towns and communities within its borders. As part of a larger project on nature tourists in wilderness areas of the Adirondack Park, hikers were interviewed in nature or wilderness areas of the Park rather than in the communities. While all respondents were participating in hiking in some way, two distinct subgroups were identified: "ADK 46ers" or those aspiring to be 46ers and "Summit Stewards". ADK 46ers are members of a club of hikers who have summited all 46 of the Adirondack's highest peaks (over 4,000 feet). Summit Stewards have chosen to work in the High Peaks region of the Park during the summer tourism season educating hikers on responsible use of the wilderness areas and how to protect its alpine vegetation. While some 46ers and Summit Stewards are Park residents, the hikers interviewed for this study are visitors and/or seasonal workers. Field research in the Adirondack Park was conducted from May through September of 2014 - the height of the tourism season. Data presented here are from in-depth semi-structured interviews (43 total) with participants ranging in age from 19 to 77, with 24 females and 19 males. All participants were United States residents who took part voluntarily and all remain anonymous, referred to by pseudonym in this paper. The researcher also kept detailed field notes, which provide additional data for the discussion that follows. Following data collection, all interviews were transcribed verbatim then thematically coded using NVivo software. Codes were not predetermined but were inductively developed, and themes were analyzed using "constant comparisons" (Corbin \& Strauss, 1990). This involves three stages of coding in discourse analysis, including open coding, axial coding, and selective coding, and allows for a thorough picture of the data organized around a central idea (Corbin \& Strauss, 1990).

Rock climbers in the Red River Gorge, Kentucky, USA

In recent decades, the Red River Gorge (The Red) of Appalachian Kentucky has become one of the world's premiere rock climbing destinations, and its popularity only continues to grow. Fieldwork in The Red took place during peak climbing season - August through 
November of 2011. This included observation of the rock climbing community, with semi-structured, in-depth interviews of lifestyle climbers, more specifically. Lifestyle climbers are individuals who have prioritized rock climbing, thereby making it a mobile lifestyle. By giving up sedentary housing and employment in order to travel and climb full-time, they maintain internet-based, and/or part-time employment as they travel. A total of 21 interviews were conducted -6 females and 15 males - representing the gender disparity of the lifestyle climber population overall. The age of participants ranged from 22 to 56 years. Mobility varied and the time spent travelling for full-time climbing extended from just six months to 17 years. Interviewees were, as reflected in the rock climbing population in general, predominantly white (Erikson, 2005). All but two interviewees were Americans, with the exception of one Canadian and one person from France. Two respondents self-identified as gay and lesbian, respectively. Pseudonyms are used to represent interviewees.

These interviews, along with fieldnotes, were transcribed with HyperTranscribe and coded in HyperResearch software applications. Analysis used an inductive approach in which themes were identified in an iterative process of multiple rounds of coding, adapted from Corbin and Strauss' (1990) three-stage process: open coding, axial coding, and selective coding.

\section{CONFRONTING ALIENATION, ANXIETY, AND AUTHENTICITY}

The notion of alienation has plagued Marxist, existentialist, and psychoanalytic thinkers for centuries. Each theoretical perspective acknowledges alienation as a condition pervasive in everyday life, while attributing it to distinct causes. Despite these distinctions, Marxism and existentialism state that alienation is among the greatest challenges to overcome, while psychoanalytic theories concede that it is an inescapable condition of human nature. Seeman (1959) articulated five manifestations of alienation: powerlessness, meaninglessness, normlessness, isolation, and self-estrangement. In what follows, we focus on the feeling of anxiety that accompanies any or all of these. Anxiety is the embodied experience of alienation. It is the feeling or sensation of uneasiness, concern, and even dread that wells up inside of us and as such motivates us to act in various ways. As these tourists illustrate, however, authenticity as an antidote to anxiety is elusive and temporally constrained.

\section{Alienation and anxiety}

For the following hikers and rock climbers, the feeling of anxiety cannot be ignored. What's more, they ascribe clear socio-spatial associations to the embodied experience of alienation and relief from anxiety.

Speaking of the tendency for anxiety to manifest itself acutely when he is separated from the wilderness, Alexander reflects,

I guess the initial sort of reactions I guess sort of wear off quickly...I guess you walk inside and you sort of have to, it's [the feeling of wholeness] not stripped away but it's kind of the 
opposite of stripped away. You get all the stuff back onto you that you went to nature to avoid in the first place.

Imogen concurs describing the moment she returns from her time in the wilderness:

Yeah, but there's always that letdown...it's almost like you recharge to your normal human self then you come back here [Syracuse] and everything slowly seeps back in. Toxic!

And Patrick adds

When I'm in New York City, maybe the first couple weeks when I get back [from the wilderness] I'm this awesome, glowing character. But if I'm there too long, I just dissolve back into the mess and the filth that everyone becomes a part of. I wonder how many people in New York City would be so strung out or complete assholes for another way to put it, it's like another Muir quote paraphrased is something to the effect of, the nerves of thousands of tired city folk coming to nature to know, rejuvenate and replenish themselves.

These manifestations of alienation relate to Seeman's (1959) descriptions of powerlessness and self-estrangement. For Alexander, Imogen, and Patrick, there is an experience of a battle with anxiety when they are away from wilderness. The alienation that comes with being in the city, Imogen describes as "toxic", as it changes individuals into what Patrick calls "assholes [...] tired city folk". This attention to the feeling of anxiety in everyday life and wilderness as a space of relief continually motivates their need for escape to "recharge to your normal human self". Importantly, though, this rejuvenation through wilderness is both fleeting and accompanied by its own feelings of angst, further suggesting a constant struggle with alienation that is pervasive.

Similarly, Leah describes rock climbing as a way to stay "sane", as it forces her to confront her feelings of anxiety associated with isolation (Seeman, 1959) and distrust that have come with her experience of alienation. While she describes her transition through rock climbing as taking place at the rock face, she credits the community of people and higher degrees of trust associated with it for easing her disquiet.

It makes me sane. I think when I first started rock climbing, I was pretty reclusive. Not reclusive, but like the idea of having to trust somebody with your life was a really interesting challenge, even more than the movement on the rock. Being like, somebody else really has a lot of you, you know. It's been good to tone down my control freakishness, I guess.

When climbing, Leah trusts her life in the hands of her belay partner. It is this necessary intimacy, as one cannot climb alone, that has challenged her reclusiveness and previous 
feelings of needing to be in control and keeps her "sane". Thus, these various ways that, Alexander, Imogen, Patrick, and Leah find relief from their feelings of anxiety are strong motivators to travel and affect their choice of destinations.

\section{Anxiety as motivation}

There is a considerable portion of the tourism literature that examines the relationship between authenticity and motivation. Yet, few studies interrogate the dialectical relationship of authenticity and alienation when investigating motivation. Many tourism scholars have touched on the distinctions between desires for escape versus seeking behaviors (see Cohen, 1979; Maoz, 2006), but few have interrogated the relationality of these motives. The ways these tourists describe their motivation reflects this dialectic, with anxiety as a motivation and seeking authenticity as a pull force.

That anxiety, as embodied alienation, is an important component of tourist motivation is illustrated by the following wilderness enthusiast who experiences acute moments of angst when he feels disconnected from wilderness. Indeed, Jerome bluntly articulates the relationship of stress relief and feeling better in wilderness to his continued motivation to return:

I mean it's like a sense of being part of something much bigger than yourself that you lose when you're not, for me at least, that's what you lose when you're not going out into these [wilderness] areas. I can feel myself...I have to go off trail and just like, get lost. And I can feel if I don't do that for a while, I start getting stressed and as soon as I do it I feel so much better, more motivated when I come back. It's definitely re-creation for me. Definitely for me, it's very spiritual. I'm not a very religious person, but I'm, yeah, it's a spiritual thing.

Indeed, for Jerome, it is not wilderness alone that offers relief, but going "off trail" and getting "lost", that temporarily alleviates his sense of self-estrangement (Seeman, 1959) allowing him to feel like himself. The stress relief of this is deeply felt, akin to a spiritual experience. For Susan, however, the anxiety of everyday is related to Seeman's (1959) meaninglessness, normlessness (anomie), and isolation manifestations of alienation, while the motivation for rock climbing is more existential and self-actualizing.

Boredom. Pure and total boredom. I didn't know anybody who rock climbed. [...] I tried like a ton of shit and none of it worked. Because I was looking for like a community and not just, I was looking for like a reason to get up in the morning. And then, I ran into climbing and totally got hooked, and now I live in a van. I was incredibly, you can't even know how antisocial I was in high school. [...] I didn't have any friends that I hung out with that I really associated with. Then in college it just started to really depress me. That was the big reason, I think that I, not necessarily, it wasn't "I must start rock climbing", but I was like I have to 
change something about my life because I'm totally miserable. $[\ldots]$ I like the person that I am trying to be when I am socializing with other people and hanging out and doing all this kind of stuff.

Thus, Jerome and Susan, as well as Carl (below), each describe a profound change in how they relate to their sense of self when they are in their everyday lives and when they are in wilderness or rock climbing. While each describes the positive experience of wilderness (Jerome) and rock climbing (Susan), they weigh their motivation as equally influenced by the negative experiences of stress, boredom, depression, and misery. Similarly, Carl describes the constraints of a lifestyle dedicated to rock climbing as nearly debilitating and restrictive. He has overcome the alienating sense of self-estrangement, but the sense of powerlessness remains (see Seeman, 1959).

I'm way tougher than I used to be. [...] So, I just feel, like, way more confident in myself, being so independent, having to take care of everything for myself. It's just like growing up I guess. I feel like it's made me tougher. And also, it's also made me, like, way more adverse to like complications, which is kind of a bummer. That's how it's made me un-tough, is I have a really hard time dealing with complicated schedules and issues. I'm like addicted to the simplicity of this. It's just so nice, you know. On my own schedule, I just chillin' basically. In that way it's made me, like, soft, and I'm not as adapted to complicated human life as most people around me are. It's a nice skill to have that ... being hardened to the busy-ness of life. It makes me, like, I tweak out. I lose it.

Carl has experienced such a profound change through lifestyle climbing that he actually fears a return to a sedentary, work-a-day livelihood. The simplicity of his rock climbing lifestyle has not left him refreshed or rejuvenated, he explains, but rather the long duration away has made the experience of alienation and the feeling of angst all the more palpable. Thus, the fear of anxiety keeps him mobile, even when he is weary of a mobile lifestyle. In feeling the most comfortable with his sense of self, he has become more aware of his weaknesses, which produces a greater feeling of anxiety about his future.

\section{Authenticity as elusive}

Forming a dialectical relationship, alienation and authenticity do not exist without each other but relationally define one another (see Kirillova, 2017). In Marxist theories, alienation from one's labor and one's fellow workers can be overcome to forge an authentic relationship in which use value is proportional to exchange value. According to existentialism, alienation can be relieved through attention to one's true self. The authentic self, however, is not ever-lasting; it is fleeting and must be continuously nurtured (see for example Kirillova, 2017). For Lacan, psychoanalytic theory suggests that alienation is constitutive of and thus permanent in the human condition, and as a result, we are driven by our desire for wholeness and the fantasy of authenticity (Knudsen et al., 2016). While the above quotes demonstrate the relationship of alienation to the 
feeling of anxiety and this feeling as a source of motivation, the fieldnotes and quotes below demonstrate the elusive nature of authenticity as one seeks relief from anxiety.

In the following excerpt from fieldnotes, the subject's disparate interpretation of the same moment - presently while hiking in poor weather conditions and the following day retrospectively describing that experience - demonstrates the temporally constraining nature of authenticity. In the moment one may experience anxiety and misery, but in recollection that experience is interpreted as visceral, embodied, and present.

17 August 2014: While hiking up the very modest Mt. Jo, I came to chat informally with another woman who was hiking alone. The day was gray and rainy, cold for August, and not ideal for fair weather hikers. Nevertheless, I had a little time to spare before my next interview so thought I'd take advantage and go for a short hike. This woman, who I will call Sally, and I walked together for a while as we made our way up Mt. Jo, and it struck me how annoyed and unhappy she seemed to be by the whole experience. Her feet hurt. She was cold. The rain was just too much, and made the rocky sections of the trail too dangerous for her liking. She couldn't wait to get to the top, take her picture, and get the hell out of there. The trail was also longer than she anticipated, and while she had heard great things about the vista from the summit, she was sorely disappointed by what she found. Owing to the fact that it was pouring rain, there (not surprisingly) wasn't much to see from the summit. Grumbling, she beat a hasty retreat from the cold, windy, wet summit in search of hot chocolate and a warm shower back at the Loj.

18 August 2014: I saw Sally again this morning just after breakfast at the Loj, and was amazed by her account of yesterday's hike. While at the time she seemed to want to be anywhere BUT on the trail doing what she was doing, today her reflection was positively glowing. I asked her if she had recovered from the hike, how her feet were doing, and asked if she planned to chill out by the lake today instead of embarking on another hiking adventure, to which she replied, "absolutely not"! Speaking of yesterday's hike, she exclaimed, "I've never felt so alive! I've never felt so...so amazingly present! Now I know why people love hiking!" Really? I'm struck dumb by how different her recollections are from what she seemed to be experiencing while we were on the mountain. I'm also shocked that after her experience yesterday, her anticipation of the next hike is that it will be this fabulously positive experience during which she will again feel, as she put it, "amazingly present". Interesting. 
In the moment, Sally felt more miserable than anything else. Yet, in retrospect her memory is of feeling alive, feeling whole, feeling present. Thus, authenticity, to the anxiety ridden alienated subject, is chimerical; its existence is a temporally sensitive fantasy. In the moment it is uncomfortable, even painful (physically and/or emotionally), yet such pain also serves as a reminder of life's fragility and by extension its value (see Wong, 2010, 2012; Wylie, 2002; 2005). The interpretation of anxiety into the authentic can only occur retrospectively, as in the moment she wants nothing more than to flee. Indeed, as she describes, in the moment she was present, the feeling of sore feet, rainsoaked clothes, and a cold body and the hazards of wet trail drowned out any ability to reflect on herself and her current situation (see Wong, 2012). As Kirillova, et al. (2017, p.644), tourists undergoing a transformative experience tend not to reflect on these existential givens in the moment but rather only later, when they begin to digest and make sense of a "triggering episode" (see also Wylie, 2005). Retrospectively, then, with the moment only a memory and the subject back under the comforts of the Loj and the weight of alienation came the rationalization that the authentic exists and indeed that it can be had and experienced. Despite authenticity's ephemeral and temporally dependent nature, the alienated subject is prompted to seek it. Indeed, she was heading out for another hike the very next day.

While one distinct moment demonstrates Sally's experience of the dialectics of alienation/authenticity, for others, like Mike, this relationship is felt at a broader time scale and accompanies larger decisions about lifestyle choice. His longing for an experience of authenticity, akin to how he used to feel about climbing, suggests he struggles with anxiety from a sense of powerlessness (Seeman, 1959) to know the right decision to make.

The lifestyle is still fun. I love it. I think part of it is being here nine months out of the year. It's like, I get so burned out. [...] Some days, I'm kind of like, ughh, I'm over this climbing thing here. I'm done, like you were saying, I do it everyday. I've been everywhere here. It's just not fun. It's boring right now. But then, just like, the beauty of it, you snap back into it. You find your motivation and then climbing's awesome. So, I don't think the lifestyle gets boring and don't think the climbing gets boring. Sometimes you just need a change. And maybe that's why I ride the fence. Maybe I just need to go somewhere else and kind of do a lifestyle like this, and maybe I need to go just get a job.

The tension among the boredom of routine, the elusive beauty of climbing, and the appeal of change makes decisions about lifestyle choice rather difficult. As Mike tries to weigh the feeling of burnout with the expectation of an epiphany that will reinvigorate his love of climbing, he experiences the anxiety of indecisiveness. He rides "the fence"; should he try climbing in a new setting; should he give up climbing and seek out full time employment? The feeling of burnout is a feeling of angst about the loss of enjoyment in his recreation and as such inspires contemplation and potential action. He yearns to 
experience the beauty of climbing and find his motivation again. His desire is to rekindle a past experience. Yet, that authentic moment is gone, as it was necessarily fleeting.

\section{DISCUSSION}

These interview data from hikers and rock climbers offer support to several theorizations of alienation, thereby demonstrating the complexity of both human nature and tourism experiences. Rather than choosing a singular framework through which to interpret these findings, we aim to foster a dialogue amongst them and advocate for further investigation of alienation in tourism motivation. While authenticity has received far more attention in tourism research, perhaps as a more optimistic approach to tourists' motivation and seeking, we argue that authenticity's dialectic, alienation, is equally important, particularly in the context of tourist motivation. Examining alienation may feel pessimistic, as a futile effort that inevitably results in dis-satisfaction with one's life. However, in the discussion below, we aim to demonstrate that alienation, and its embodiment as anxiety, are crucial factors in particular types of tourism motivation. And while one cannot ever fully overcome the alienating conditions of society, this drive towards the authentic is an important means through which one gains meaningful experiences, personal growth, self-reflection, and the motivation to repeatedly venture into the world in search of the potential for such moments. As Kirillova, et al. (2016, p.9; 2017) assert, "[a]nxiety makes one face existential predicaments and initiate actions toward reclaiming one's personal value system".

\section{Marxist alienation}

Throughout the quotes above, we can hear echoes of Marxist interpretations of capitalism and the alienation caused in relation to these tourists' motivation. MacCannell's (1976, 1999) elaboration of the ritual structure of sightseeing is rooted in the notion that as alienated subjects of late capitalism, we seek the authentic and a sense of commonality with our fellow citizens through tourism. In other words, tourism offers escape from the everyday stress of life, but it also offers a glimpse of the authentic as a counterforce to our everyday alienation. While this formulation has been more readily applied to sightseeing, considering Marx's notions of alienation in terms of alienation from "nature" in a tourism context opens up another perspective for alienation and anxiety as adventure tourism motivation.

While Marx's philosophy has often been deemed decidedly anti-ecological at worst or only secondarily or tangentially related to nature at best, connections between alienation and "nature" may be seen as central in much of his thinking (see O'Connor, 1998; Foster, 2000). As Foster (2000) points out, "Marx's concept of the alienation of labor - was inseparable from the alienation of human beings from nature, from both their own internal nature and external nature" (p.72, emphasis added). In this way, people have become alienated from their land, from nature, from themselves, and from each other as a result of their inability to actively engage with nature. Marx notes that this alienation "estranges man from his own body, from nature as it exists outside him, from his spiritual 
essence, his human essence" (1844 cited in Foster 2000, p.73, original italics). The relationship between humans and nature is, according to Marx, a fundamental one, for without it humans remain in an alienated state. The solution, for Marx, is to be found in bodily practice, in action rather than in thought, in physical, material practice that connects nature and individual (Foster, 2000, p.78). Foster notes, "According to Marx, we transform our relation to the world and transcend our alienation from it - creating our own distinctly human-natural relations - by acting, that is, through our material praxis" (p.5, original italics).

In the quotes from hikers and rock climbers above, descriptions of the importance of physical practice and the material setting are at the heart of the socio-spatial associations of alienation/anxiety and authenticity. These tourists describe the ways being in wilderness rejuvenates "tired city folks" and removes the "toxic" residue that stress, work, and social obligation build up. The embodied praxis of time spent in wilderness and/or rock climbing foregrounds action rather than thought, and as such, eases the anxiety that accompanies alienation in everyday life. Yet, a Marxist critique cannot account for all of the experiences presented above. In particular, the ways that some described fleeting moments of being present more fully support existentialist perspectives.

\section{Existential alienation and authenticity}

Although existentialists such as Heidegger, Sartre, and Buber maintained that humans are born into alienation (see Buber, 1937), it has also been argued that alienation, part of what is known as the "existential predicament", is a necessary condition of existential anxiety (see Kirillova, et al., 2017). As such, it has been suggested that a way towards existential authenticity is by breaking from society, spatially and/or socially. This has been the impetus of its application in tourism studies, as tourism offers the opportunity for a break from the everyday. In particular, Cohen's (1979) work linked an individual's experience of alienation with his/her mode of tourism and Brown (2013) terms tourism a catalyst for existential change in one's life. Further, Maoz (2006, p.61) observes, "[w]hile the sense of alienation serves as a kind of a pull factor towards an alternative centre when combined with the image of the tourist destination, the sense of a personal crisis provides a socio-psychological push factor." Indeed, hikers in the Adirondacks describe moments of stress in everyday life that motivate their need get away from the city, rejuvenate, and recharge to their "normal" selves.

More specifically, Wang (1999, p.363) suggests tourists "attempt self-creation through seeking suitable challenges found in nature and from adventures". It is by exercising control over one's physical, biological self, he contends, that alienated individuals may experience their true, authentic selves. Thus, Wang argues for nature and adventure tourism as avenues that lead to the possibility of self-realization and freedom from alienated modern existence, albeit a temporary one. Several of the tourists quoted above describe just such a scenario. By traveling away from their everyday lives into wilderness and/or through the act of rock climbing, they have encountered and fostered a new sense of self. Their identities and how they relate to the world have changed, and most like these changes, as they describe themselves as feeling more "sane", "present", 
"confident", and "independent". In fact, one explained, "I like the person that I am trying to be", suggesting these experiences of self are not simply achieved in transformative moments, but must be maintained and continually practiced in the face of changing personal and social conditions. Indeed, as Kirillova (2017, p. 639) assert, "[t]ransformative tourist experiences mandate a conscious effort on the part of an individual and could involve changes in understanding the self, revision of one's belief system, and alterations in one's behavior and lifestyle" (see also Maoz, 2006). Thus, while alienation and anxiety are motivating, tourists must continually strive to maintain any renewed sense of self or re-creation they may enjoy during a transformative experience.

Relatedly, most existentialists argue that the authentic moment and the authentic self are ephemeral. One cannot sustain authenticity, but rather it is experienced in discreet moments (see Steiner \& Reisinger, 2006). What's more, both Heidegger (1927/1962) and Sartre (1939/2002) theorized that authenticity is accompanied by a feeling of anxiety. As such, being in the moment of the existentially authentic experience is not the pleasurable experience we may rationalize it to be, or that some tourism scholars report (see Cohen, 1979; Wang, 1999; Kim \& Jamal, 2007; Buchman, et al., 2010; author, 2012). While some experiences of existential authenticity may indeed bring moments of calm, we argue that they are also accompanied by feelings of anxiety that are both temporal and existential in nature (Wearing, et al., 2016). Anxiety is the experiential vehicle for alienation, and while tourists may experience moments of existential authenticity, the omnipotence of alienation forecloses the possibility of having an experience totally lacking in anxiety. It is, therefore, important that we attend to existential anxiety as "[a]n essential yet less studied counterpart of existential authenticity" (Kirillova, et al. 2016, p.2; 2017). Informed by the work of Kierkegaard, Heidegger, and Sartre, Kirillova, et al. (2016) describe existential anxiety as a "diagnostic tool", "feeling of uneasiness", and an "alarm", which prompts action in the individual to pursue a sense of true self. Tourism is just one of the avenues through which this pursuit takes shape. Indeed, the hikers and rock climbers examined in this paper demonstrate the relations of anxiety to experiences of both alienation and authenticity. In particular, the disparity in Sally's in-the-moment experience of hiking in the cold and rain compared to her next day recollection serves as an example of the displeasure of the authentic moment when it is happening and the ways one reconsiders the experience as a memory. Similarly, those rock climbers who have turned the sport into a form of lifestyle travel continue to struggle with the anxiety of their decision. Indeed, anxiety remains a component of their everyday lives even though they have made travel and recreation into a lifestyle.

Thus, attention to the ways anxiety is experienced as alienation embodied in relation to touristic motivation suggests it is a direly underexplored dialectic of authenticity. However, that some of these nature tourists speak to the unabating presence of anxiety, even in the authentic moments of tourism, means that perhaps existentialist theories cannot fully account for this experience. It is in these instances that the potential applicability of psychoanalytic theories must also be considered. Here we focus particularly on Lacanian psychoanalysis and his conception of fantasy. 


\section{Lacanian alienation and the fantasy of authenticity}

Lacan theorized that alienation is a condition of being human. We cannot escape it, and as such, authenticity is a fantasy. Knudsen et al. (2016) assert that the fantasy of authenticity operates through tourism as a motivating factor in our travels. It is the story we tell ourselves about where authenticity might be found - in other places, other communities, other times. Yet, when we break from our everyday lives and travel in search of the authentic, it remains elusive and just outside our grasp. As Oakes (2006) contends, authenticity fades the moment we approach it.

Several of the hikers and climbers above speak of the tension between anxiety and the authentic. Yet, none is able to articulate authenticity in the moment of the experience. Authenticity is described retrospectively or as a potential future experience. Thus, Lacan would suggest this is the fantasy of authenticity actively at work. That authenticity is fantasy does not, however, denude or degrade its critical function in our lives. Rather, the fantasy of authenticity is one that has a profound structuring effect, motivating us and protecting us from the Real and its attendant traumas (Lacan, 1949/2006; Homer, 2005; Bailly 2009). The protective function of fantasy in the face of alienation must not be ignored, and can be seen in the anxieties and uncertainties of hikers and climbers. For instance, lifestyle rock climbers describe anxieties that frame their decisions to continue lifestyle travel for the sport. These anxieties, Lacan might contend, highlight moments of the Real peeking through. While a sense of alienation may have encouraged them to pursue climbing full-time, in doing so they have not achieved an authentic lifestyle but rather face anxieties related to indecisiveness and awareness of their own vulnerabilities.

Because we are all alienated subjects and experience what Lacan calls "lack", we must necessarily believe that an unalienated self exists and we must pursue it as we attempt to combat our feelings of lack. This lack, however, may never be adequately filled or its anxieties fully assuaged, but can only motivate us to seek moments during which we might benefit from engagement with the fantasy of authenticity. That those moments during which we feel or experience authenticity are accompanied by anxieties is further evidence of our alienation as constitutive, for while we engage with the fantasy, there is no single enduring experience of pure authenticity or pure self. Thus, hikers and climbers who find themselves feeling somehow less whole, less truly themselves, less calm, or more fearful upon leaving the wilderness or pursuing a lifestyle of climbing are engaging more fully with their own alienation rather than losing a fully authentic self. It is this very experience of the dialectic of alienation/authenticity that will perpetually motivate their desires to escape everyday life, travel towards such destinations, and experience moments of temporary relief.

\section{CONCLUSION}

While authenticity constitutes a well-worn theoretical path in tourism literature, scholarship to date has underexplored notions of alienation. Even as explorations of alienation have gained more traction in the tourism literature, there has been very little investigation into anxiety and its relationship with both alienation and authenticity in tourist motivation. This paper has sought to articulate anxiety as embodied alienation and 
to further explore the relations among anxiety, alienation, and authenticity via the experiences of hikers and rock climbers and through the three major theoretical advancements on alienation/authenticity in tourism studies: Marxism, existentialism, and psychoanalysis.

Importantly, this research draws attention not only to anxiety as embodied alienation but also to the anxiety present in experiences of authenticity, and in so doing engages alienation/authenticity as dialectical. For the hikers and rock climbers in this study, authenticity is an experience that lies at the horizon, in the next adventure, or in the past as a memory, and thus serves as a beacon, a siren song that inspires and drives the tourist. Their accounts demonstrate the dialectical relationship of alienation and authenticity in that while experiences of authenticity are approached as being positive, restorative, and rejuvenating, particularly in existential contexts, authenticity also contains elements of anxiety and fear, equally motivating to the tourist yet pushing rather than pulling them towards particular destinations (see Maoz, 2006). Thus, rather than assign value to alienation, anxiety, or authenticity, our aim here has instead been to bring them into conversation with one another through a variety of theoretical lenses in an attempt to better understand how each serves to motivate, either as a push factor or pull factor (see Maoz, 2006). As mutually constitutive, alienation and authenticity maintain a dialectical relationship; each has within it the seeds of the other and both motivate touristic pursuits. As alienation embodied, anxiety is an acute motivator pushing tourists to seek the authentic, whereas authenticity is a fantasy (see Knudsen, et al., 2016), and while it may be experienced (Wang, 1999; Kirillova et al., 2017), those experiences are both temporally constrained and fraught with their own anxieties.

Our aim here is to avoid value judgments that accompany interpretations of alienation/authenticity, and instead illustrate the ways push and pull factors work in tandem to motivate tourist behaviors. One can never overcome or fully assuage acute feelings of anxiety as alienation and one can never fully experience authenticity, as it is elusive. Yet, they remain essential to tourism motivation and experience. What's more, anxiety accompanies both dimensions of the alienation/authenticity dialectic. As Kirillova, et al. (2016, p.9) maintain, tourism offers a liminal space which "distances individuals from the everydayness and removes the protective shield to expose angst". This, however, is not the final outcome. Exposing anxiety results in further actions towards various ends, which these tourists demonstrate: further pursuit of the authentic in new tourism experiences, return home feeling refreshed and planning the next adventure, committing to a lifestyle of travel and avoiding the stress of the everyday. These hikers and lifestyle rock climbers describe just some of the ways the dialectical relationship of alienation/authenticity inspires their needs for escape and desires for experience.

While adventure tourists, nature tourists, and self-proclaimed adrenaline junkies (of which hikers and rock climbers have been variously categorization by different authors (see Palmer, 2002; Kane \& Tucker, 2004; Varley, 2006, 2011; Davidson \& Stebbins, 2011; Fletcher, 2014; Rickly \& Vidon, 2017; Author 2016, 2017)) all provide rich opportunities for understanding motivations and the dialectical relationship between alienation and authenticity, further theorizations and empirical explorations of this 
alienation/authenticity dialectic may be enriched by expanding study out to other groups of tourists. Nature tourists and those seeking authenticity in both site and self in what may seem like obvious places (alone on a rock face, for instance), while important, are only part of the tourism story. The current context is conducive to conversations about authenticity, alienation, existentialism, and the relationships between them, but what about mass tourism? Future study may expand these ideas and ask similar questions about the role of alienation and anxiety in mass touristic pursuits ostensibly focused on hedonic consumption (see Hirschman \& Holbrook, 1982) and hedonic well-being (see Chen, 2011). Attention to alienation as the dialectic of authenticity in various subfields of tourism is sure to further enhance our understanding of both phenomena, and the ways they interact.

\section{REFERENCES}

Author, 2012

Author, 2013

Author, 2016

Author, 2017.

Bailly, L. (2009). Lacan: A beginner's guide. Oxford: Oneworld Publications.

Brown, L. (2013). Tourism: A catalyst for existential authenticity. Annals of Tourism Research, 40: 176-190.

Buber, M. (1937). I and thou. New York, NY: Charles Scribner's Sons.

Buchmann, A., Moore, K., Fisher, D. (2010). Experiencing film tourism: Authenticity and fellowship. Annals of Tourism Research, 37(1): 229-248.

Chen, Y. (2011). Powerful programs or predisposed participants? The effect of vacation on travelers' subjective well-being (Unpublished doctoral dissertation). Purdue University, West Lafayette, IN.

Cohen, E. (1979). A phenomenology of tourist experiences. In Y Apostolopoulos, S Leivadi, and A Yiannakis (Eds.), The sociology of tourism: Theoretical and empirical investigations (90-114). New York, NY: Routledge.

Corbin, J. \& Strauss, A. (1990). Grounded theory research: Procedures, canons, and evaluative criteria. Qualitative Sociology, 13(1), 3-21.

Dann, G.M.S. (1977). Anomie, ego-enhancement and tourism. Annals of Tourism Research, 4, 184-194. 
Davidson, L. and Stebbins, R. (2011). Serious leisure and nature: Sustainable consumption in the outdoors. London: Palgrave MacMillan.

Erikson, B. (2005). Style matters: Explorations of bodies, whiteness, and identity in rock climbing. Sociology of Sport Journal, 22, 373-396.

Fletcher, R. (2014). Romancing the wild: Cultural dimensions of ecotourism. Durham, NC: Duke University Press.

Foster, J.B. (2000). Marx's ecology. New York, NY: Monthly Review Press.

Heidegger, M. (1927/1962) Being and time, Oxford, Blackwell.

Hirschman, E. \& Holbrook, M. (1982). Hedonic consumption: Emerging concepts, methods and propositions. Journal of Marketing, 46(3), 92-101.

Homer, S. (2005). Jacques Lacan. New York, New York: Routledge.

Kane, M. \& Tucker, H. (2004). Adventure tourism: The freedom to play with reality. Tourist Studies, 4(3), 217-234.

Kierkegaard, S. (1844/1980) The Concept of Anxiety, Princeton, Princeton University Press.

Kim, H. \& Jamal, T. (2007). Touristic quest for existential authenticity. Annals of Tourism Research, 34(1): 181-201.

Kingsbury, P. (2010). Locating the melody of the drives. The Professional Geographer, 62(4), 519-533.

Kingsbury, P. (2011). Sociospatial sublimation: The human resources of love in Sandals Resorts International, Jamaica. Annals of the Association of American Geographers, 101(3), 650-669.

Kingsbury, P., Crooks, V., Snyder, J., Johnston, R., \& Adams, K. (2012). Narratives of emotion and anxiety in medical tourism: On State of the Heart and Larry's Kidney. Social \& Cultural Geography, 13(4), 361-378.

Kirillova, K. \& Lehto, X. (2015) An existential conceptualization of the vacation cycle. Annals of Tourism Research, 55(1), 110-123.

Kirillova, K., Lehto, X., \& Cai, L. (2016). Existential authenticity and anxiety as outcomes: The tourist in the experience economy. International Journal of Tourism Research. DOI: 10.1002/jtr.2080. 
Kirillova, K., Lehto, X.,\& Cai, L. (2017). Tourism and existential transformation: An empirical investigation. Journal of Travel Research, 56(5), 638-650.

Knudsen, D., Rickly, J., \& Vidon, E. (2016). The fantasy of authenticity: Touring with Lacan. Annals of Tourism Research, 58, 33-45.

Lacan, J. (1949/2006). Ecrits. (B. Fink, Trans.). New York, NY: W.W. Norton \& Company. (Original work published 1966).

MacCannell, D. (1976). The tourist: A new theory for the leisure class. New York, NY: Schocken Books.

Maccannell, D. (1999). The Tourist: A new theory of the leisure class, $2^{\text {nd }}$ edition. Berkeley, University of California Press.

MacCannell, D. (2002). The ego factor in tourism. Journal of Consumer Research, 29(1), 146-151.

Maoz, D. (2006). Erikson on the tour. Tourism Recreation Research, 31(3), 55-63.

Marx, K. \& Engels, F. (1846/2007). The German ideology. New York, NY: International Publishers.

Oakes, T. (2006) Get real! On being yourself and being a tourist. In C. Minca and T. Oakes (Eds.), Travels in paradox: Remapping tourism (229-250). Lanham, MD: Rowman and Littlefield Publishers, Inc.

O’Connor, J. (1998). Natural causes: Essays in ecological Marxism. New York, NY: Guilford Press.

Palmer, C. (2002). 'Shit happens': The selling of risk in extreme sport. The Australian Journal of Anthropology, 13(3), 323-336.

Rickly, J. \& Vidon, E. (2017). Contesting authentic practice and ethical authority in adventure tourism. Journal of Sustainable Tourism, 25(10), 1418-1433.

Sartre, J. P. (1939/2002) Sketch for a theory of the emotions, London, Routledge.

Seeman, M. (1959). On the meaning of alienation. American Sociological Review, 24(6), 783-791.

Steiner, C.J. \& Reisinger, Y. (2006). Understanding existential authenticity. Annals of Tourism Research, 33, 299-318.

Turner, C. \& Manning, P. (1988). Placing authenticity - On being a tourist: A reply to 
Pearce and Moscardo. Australia and New Zealand Journal of Sociology, 24, 136139.

Varley, P. (2006). Confecting adventure and playing with meaning: The adventure commodification continuum. Journal of Sport \& Tourism 11(2): 173-194.

Varley, P. (2011). Sea kayakers at the margins: The liminoid character of contemporary adventures. Leisure Studies 30(1): 58-98.

Wang, N. (1999). Rethinking authenticity in tourism experience. Annals of Tourism Research, 26(2): 349-370.

Wearing, S. L., Mcdonald, M. \& Ankor, J. (2016) Journeys of creation: Experiencing the unknown, the Other and authenticity as an epiphany of the self. Tourism Recreation Research, 41(2): 157-167.

Wong, P. (2010). Meaning therapy: An integrative and positive existential psychology. Journal of Contemporary Psychotheraphy, 40(2): 85-99.

Wong, P. (Ed.). (2012). The human quest for meaning: Theories, research, and applications ( $2^{\text {nd }}$ ed.). New York: Routledge.

Wylie, J. (2002) An essay on ascending Glastonbury Tor. Geoforum, 22(3), 441-454.

Wylie, J. (2005) A single day's walking: narrating self and landscape on the South West Coast Path. Transactions of the Institute of British Geographers, 30(234-247.

Xue, L., Manuel-Navarrete, D., \& Buzinde, C.N. (2014). Theorizing the concept of alienation in tourism studies. Annals of Tourism Research, 44, 186-199. 